MJCCA9 - 605

\title{
BEHAVIOR OF THE TRANSPORT AND SEPARATION OF LANTHANUM, YTTRIUM AND LUTETIUM METAL IONS THROUGH A CELLUOSE FIBER SUPPORTED SOLID MEMBRANE
}

\author{
Abai G. Gaikwad \\ Chemical Engineering \& Process Development Division, National Chemical \\ Laboratory, Pune 411 008, India \\ ag.gaikwad@ncl.res.in
}

\begin{abstract}
A newly designed membrane cell was used to study the behavior of the transport and separation of lanthanum, yttrium and lutetium metal ions using a cellulose fiber supported solid membrane. The cellulose fiber membrane was prepared by the chemical modification of cellulose fiber using an esterification reaction with citric acid. Different experimental variables were investigated, such as time, membrane size, stirring of the source and receiving phases and the $\mathrm{pH}$ of the source phase. The use of different stripping agents in the receiving phase was explored, including nitric acid, hydrochloric acid, sodium nitrate, ammonium thiocyanate, D EHPA, TBP, Aliquat-336, tartaric acid, EDTA and organic solvents. Pre-concentration of lanthanum, yttrium and lutetium metal ions from dilute solutions was carried out.
\end{abstract}

Key words: cellulose fiber membrane; lanthanum; yttrium; lutetium; metal ions; transport studies; separation; complexing reagent; binary mixture; citric acid

\section{КАРАКТЕРИСТИКИ НА ТРАНСПОРТОТ И СЕПАРАЦИЈАТА НА МЕТАЛНИТЕ ЈОНИ НА ЛАНТАН, ИТРИУМ И ЛУТЕЦИУМ ПРЕКУ ЦЕЛУЛОЗНИ ВЛАКНА НАНЕСЕНИ НА ЦВРСТА МЕМБРАНА}

\begin{abstract}
Користена е новодизајнирана мембрана за да се испитаат карактеристиките на транспортот и сепарацијата на металните јони на лантан, итриум и лутециум со помош на целулозно влакно нанесено на цврста мембрана. Целулозното влакно од мембраната беше подготвено со негова хемиска модификација во реакција на естерификација со лимонска киселина. Во текот на транспортот се следени различни експериментални параметри: влијание на времето, димензии на мембраната, мешање на почетната и крајната фаза при транспортот и рН на почетната фаза. Покрај тоа, во крајната фаза е испитана примената на различни средства за отстранување-азотна киселина, хлороводородна киселина, натриумнитрат, амониумтиоцијанат, D EHPA, TBP, Aliquat-336, винска киселина, EDTA, органски растворувачи итн. Изведена е пре-концентрација на јоните на металите на лантан, итриум и лутециум.
\end{abstract}

Клучни зборови: мембрана со целулозно влакно; лантан; итриум; лутециум; метални јони; испитување на транспорт; сепарации; реагенси за комплексирање; бинарни смеси; лимонска киселина 


\section{INTRODUCTION}

Since rare earth elements are similar in their chemical and physical properties, many attempts had been made to separate them from each other. In the literature, to cite a few references in the progress of rare earth metal ion separation, the effect of anions such as perchlorate, chloride, nitrate and acetate on the separation of rare earths was studied using a cation exchange membrane composed of 5,11,17,23-tetra-tert-butyl25,26,27,28-tetrakis-(di-phenyl-phosphinoylmethoxy)-calix[4]-arene (cone conformation) in $o$-nitrophenyl hexyl ether (NPHE) [1-2]. Citric acid under selected experimental conditions of ion exchanger bed height and diameter has been found to be useful for the separation of rare earth elements. Solvent extraction has been reported for rare earth elements with a macrocyclic ligand [3]. A process was demonstrated for the efficient separation of rare earth elements, using a combination of selective reduction and vacuum distillation of halides [4]. The effect of the substitution of rare earth metal ions in the membrane for the separation of water and acetic acid has been reported [5]. The separation of rare earth metal ions has been reported using a micro-column ( $0.5 \mathrm{~mm}$ i.d. and $75 \mathrm{~mm}$ long) packed with TSK LS-212 high-performance cation exchange resin [6]. The separation of adjacent rare earth metals was improved using the difference in complex formation ability between metals and EDTA [7]. The separation of rare earth metals has been investigated using microcapsules (MC) consisting of a styrene ( $\mathrm{St}$ )-divinylbenzene (DVB) copolymer containing bis-(2-ethylhexyl)-phosphinic acid (PIA-226) [8]. Also, centrifugal countercurrent type chromatography (centrifugal partition chromatography) has been applied for the separation of lighter rare earth metal ions, i.e. $\mathrm{LaCl}_{3}$, $\mathrm{CeCl}_{3}, \mathrm{PrCl}_{3}, \mathrm{NdCl}_{3}, \mathrm{SmCl}_{3}$ and $\mathrm{EuCl}_{3}$ [9]. The use of pressurized ion exchange chromatography for the rapid separation of rare earth elements was demonstrated using Dowex 50W-X8 and $\alpha$-hydroxyisobutyrate solution [10]. Anionic complexes of rare earth elements were separated isocratically using anion-exchange resin and ethylenediaminetetraacetic acid (EDTA) as the mobile phase [11]. The separation of samarium using a hollow fiber membrane has also been described [12].

Since the rare earth elements are very similar in their chemical and physical properties, developing separation methods for clean and clear-cut separation for rare earth elements is a challenging task. Several attempts in the past have been made to develop selective separation methods for the rare earth elements. Besides these efforts, the task remains economically challenging. However, citric acid has been used as an eluant in the separation of rare earth metal ions using a cation exchange resin bed in the column [13]. Tartaric acid and EDTA have been used as complexing reagents for rare earth metal ions [14]. $\mathrm{HCl}$ and $\mathrm{HNO}_{3}$ have been used as stripping agents in liquid-liquid extraction and as eluants in ion exchange chromatography for rare earths [15]. $\mathrm{D}_{2}$ EHPA and beta-diketones have been used as the extractant for rare earth metal ions [16-18]. Organophosphorus extractants, napthenic and versatic acids have been explored for the separation of rare earth metal ions [19-24].

There are several reports on the transport and separation of rare earth elements using liquid membrane techniques. Different extractants were explored in these studies, such as $\mathrm{D}_{2} \mathrm{EH}-$ PA, PC-88A and Aliquat-336 [25-27]. During these investigations, different strippants in the receiving phase included mineral acids and carboxylic acids [28-30]. Hollow fiber membrane solvent extraction and supported liquid membrane techniques have been explored for transportive separation, enrichment and recovery of rare earth metals ions [31-40]. However, there has been no positive outcome for the commercial process in terms of of economically viable separation due to some drawbacks of the supported liquid membrane system. Therefore, it is worthwhile to explore new ways to achieve the transportive separation of metal ions using a supported membrane system.

The ion exchange studies of some metal ions have been explored in mixed solvent 
systems since these metal ions form chlorocomplexes in a mixed solvent using different organophosphorus extractants, where the two mechanisms of ion exchange and solvent extraction are involved [41-46]. However, in the present investigation, the ion transport studies of rare earth elements were carried out using a chemically bonded citric acid phase on cellulose fiber, which enhanced the selective transport of rare earth metal ions by utilizing both ion exchange and solvent extraction mechanisms. The extraction and stripping processes were simultaneously carried out in a single step. Moreover, attempts were made to explore the transportive behavior of lanthanum, yttrium and lutetium metal ions through the immobile citric acid on cellulose fibers using tartaric acid, EDTA, $\mathrm{HCl}, \mathrm{HNO}_{3}, \mathrm{NH}_{4} \mathrm{SCN}, \mathrm{D}_{2} \mathrm{EHPA}$ (diethyl hexyl phosphoric acid), beta-diketones, napthenic acid and versatic acids in the mixed solvent in the receiving phase.

Design and development based on chemically modified fiber supported solid membranes is an emerging, versatile technique for the transport and separation of several metal ions. The advantages of fiber supported solid membranes are that there is no loss of solvent, the flow rates of the source and receiving phases can be controlled and the desired solid membrane phase can be chemically attached to a fiber for selective separation. Moreover, the amount of time required can be controlled by increasing or decreasing the length of the fiber solid membrane. In addition to this, citric acid is environmentally friendly, non-polluting and forms metal complexes with several metal ions. Yttrium is associated with the rare earth elements and also resembles the rare earth elements in terms of its chemical and physical properties. In solvent extraction using nitrate and thiocyanate media, yttrium behaves like heavy rare earth elements, but yttrium behaves like light rare earth elements in thiocyanate medium with Aliquat-336. Therefore, one interesting aspect is to explore the transport behavior of yttrium along with lanthanum and lutetium using the cellulose fiber membrane technique. The aim of this paper was to explore a chemically modified cellulose fiber membrane for the transport and separation of lanthanum, yttrium and lutetium metal ions.

\section{EXPERIMENTAL SECTION}

\subsection{Reagents and apparatus}

All chemicals used were of analytical grade. EDTA was standardized by titration with thorium nitrate solution. Lanthanum metal ions were analyzed by the oxalate gravimetric method. Low concentrations of rare earth metal ions were determined by spectrophotometrically using an Arsenazo III reagent. Higher concentrations of rare earth metal ions were determined by EDTA titration using xylenol orange or Alizarin Red S as indicators. Cellulose porous solid fibers (Aldrich Chemicals) were used for the preparation of the modified cellulose fiber supported solid membrane. Tributyl phosphate (TBP), methanol, ethanol, 2-propanol, acetone, tetrahydrofuran and 1,4-dioxane (Aldrich Chemicals CO, USA) were used without further purification. Dilute acid solutions were prepared from concentrated acid solutions (Merck, India Ltd.,) in distilled and de-ionized water. Most stock solutions of metal ions were prepared from their chlorides or nitrates. The concentration of metal ions in the solution was analyzed by EDTA titration, or gravimetry or spectrophotometry, depending on the metal ion concentration.

\subsection{Cellulose fiber membrane synthesis}

The fibers were used with a diameter of $0.027 \mathrm{~cm}(270 \mu \mathrm{m})$ and porosity 30 to $50 \%$. The cross-section area of the porous fibers was 5.73 $\times 10^{-4} \mathrm{~cm}^{2}$. The amount of aqueous solution in the porous fiber was calculated by weighing the porous solid fibers before and after soaking in an aqueous solution. The cellulose fibers were modified by the following scheme. 


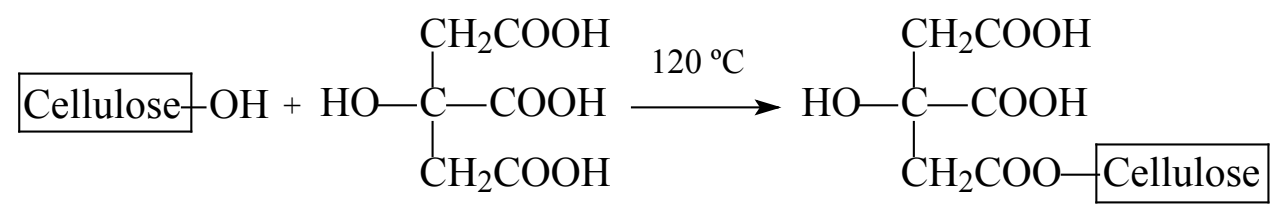

Scheme 1. Chemical modification of cellulose fibers with citric acid

The pre-treated cellulose fiber was treated with $0.5 \mathrm{M}$ citric acid at a ratio of $1: 12$ (cellulose fiber:acid, $w / v$ ) and stirred for $30 \mathrm{~min}$. The acid/cellulose fiber slurry was placed in a stainless steel reactor and dried at $50^{\circ} \mathrm{C}$ in a forced air oven. After $24 \mathrm{~h}$, the thermochemical esterification between the acid and the cellulose fiber was carried out by raising the oven temperature to $120^{\circ} \mathrm{C}$ for $90 \mathrm{~min}$. After cooling, the esterified cellulose fibers were washed with distilled water until the filtrate was free of citric acid (tested as no turbidity with 0.1 $\mathrm{M}$ lead (II) nitrate solution). After filtration, the esterified cellulose fiber product was suspended in $0.1 \mathrm{M} \mathrm{NaOH}$ at a suitable ratio and stirred for $60 \mathrm{~min}$, followed by thorough washing with distilled water to remove residual alkali; the wet modified cellulose fibers were then dried at $50^{\circ} \mathrm{C}$ for $24 \mathrm{~h}$ and preserved in a desiccator until use. Before use, if necessary, the cellulose fiber product was converted into acidic form with acid treatment [47-52]. The chemically modified fibers were designated as a fiber supported solid membrane. Metal ion transport studies were carried out through the fiber supported solid membrane. A Teflon tube with an o.d. of $0.4 \mathrm{~cm}$ and an i.d. of $0.2 \mathrm{~cm}$ was used as the support for the fiber supported solid membrane.

\subsection{Procedure}

A source solution was used with a rare earth metal ion concentration in the range from $10^{-6}$ to $10^{-2} \mathrm{M}$ in $15 \mathrm{ml}$ in the source compartment of the cell. The receiving phase used was $15 \mathrm{ml}$ of an appropriate concentration of acid or mixed solvents of acid, Aliquat-336 and organic solvents in the receiving compartment of the cell. The $\mathrm{pH}$ of the source solution was adjusted with dilute hydrochloric acid and sodium hydroxide solutions. The source and receiving solutions were connected by the fiber supported solid membrane (supported in a Teflon tube with an o.d. of $0.4 \mathrm{~cm}$ and an i.d. of $0.2 \mathrm{~cm}$ ) (Figure 1). Samples of the source and receiving solutions were withdrawn and analyzed. The permeability coefficients were determined for the analysis of data. The experiments were carried out at room temperature.

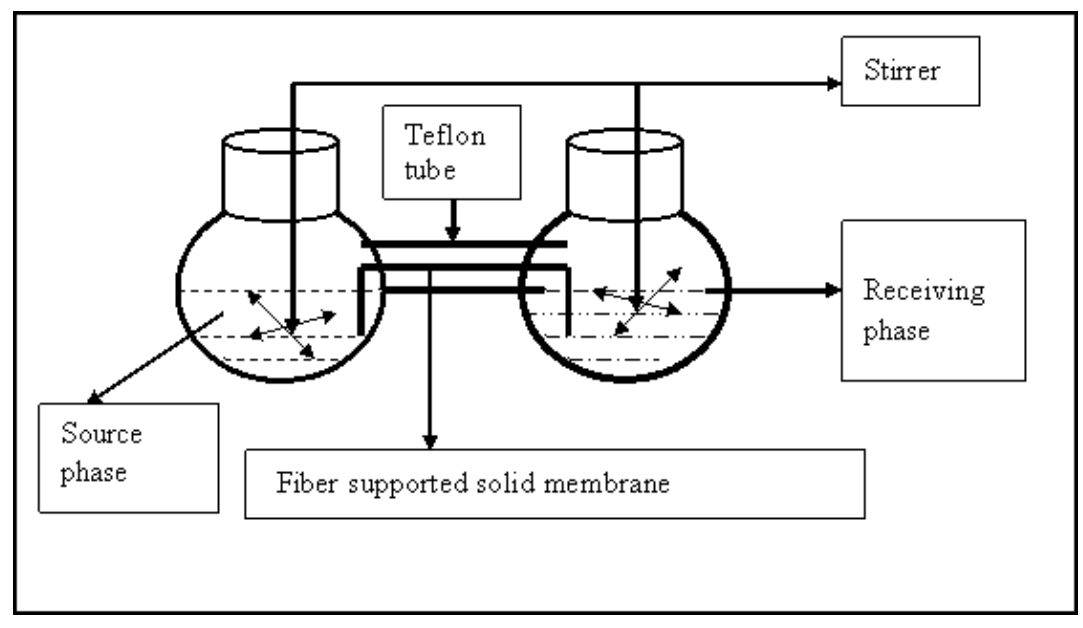

Fig. 1. The schematic presentation of the fiber supported solid membrane cell 


\section{RESULTS AND DISCUSSION}

\subsection{Mechanism of metal ion transport}

In the fiber supported solid membrane technique, the separation mechanisms involved are ion exchange and the diffusion of metal ions through the fiber supported solid membrane. The source phase, membrane and receiving phase are stationary phases and there is no mobile phase. The fiber plays the role of the support. The driving force for the transport of metal ions is the gradient concentration of chemical species. Due to the large surface area and capillary action of fine fibers, the microfibers can absorb liquid up to seven times its weight. Moreover, the water molecules in the cellulose fibers are held together by hydrogen bonding. The cellulose porous microfibers are extremely durable and effective, even after several uses. It is an exceptionally cost-effective product.

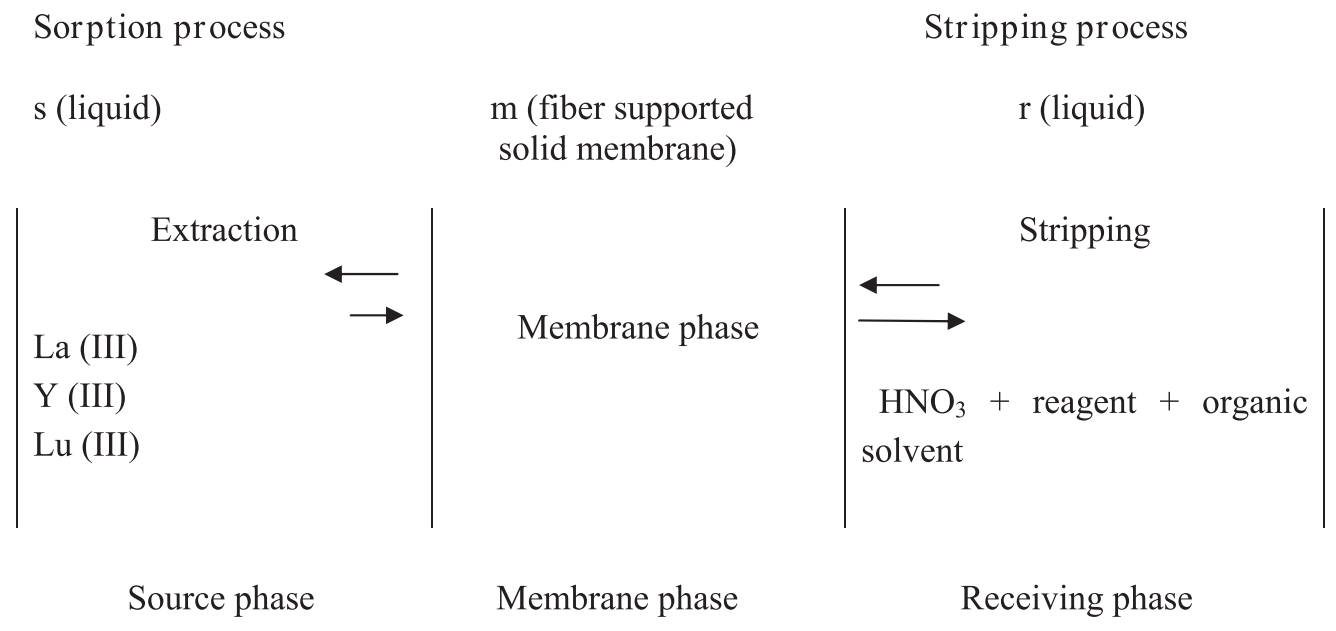

Fig. 2. Illustration of the transport of metal ions through the fiber supported solid membrane

In the fiber supported solid membrane technique, the mechanism of metal ion transport from the source to the receiving phase occurs through the fiber supported solid membrane, as illustrated in Figure 2. There is no continuous flow of a mobile phase, either from the source or the receiving phase, through the fiber supported solid membrane. The capillary action mechanism in the porous fiber helps to maintain liquid in the fiber during the transport of metal ions. However, transport of metal ions from the source through the membrane to the receiving phase occurs due to the driving forces of the receiving phase. Moreover, ion exchange and the diffusion of chemical species through the fiber supported solid membrane are the important aspects responsible for the transport of metal ions. In the fiber, the supported solid membrane phase (chemically bonded to citric acid) is used as the membrane barrier in between the source and receiving phases. The driving forces of the salt, acid and mixed solvent compositions in the receiving phase enhance metal ion transport.

\subsection{Determination of the permeability coefficient}

For the calculation of the permeability coefficient $(P), C^{s}{ }_{0}$ is the concentration of the metal ion in the source phase at $t=0$ and $\left(C^{s}\right)$ is the change in the concentration of the metal ion in the source phase with respect to time $(t)$ through a cross-sectional area $(A)$; the volume of the source phase $\left(V_{s}\right)$ and the fiber column membrane phase length $(l)$ can be incorporated into equation (2), where $k$ is a rate constant. 


$$
-\frac{d C_{t}^{s}}{C_{0}^{s}}=\frac{k \cdot A \cdot d t}{V_{s} \cdot l}
$$

After integrating equation (1), the permeability coefficient $(P)$ for the transport of metal ions is obtained by equation (2).

$$
\ln \frac{C_{t}^{s}}{C_{0}^{s}}=-\frac{P \cdot A \cdot t}{V_{s} \cdot l}
$$

The calculated permeability coefficient $(P)$ is used to interpret the data of metal ion transport through the porous solid fiber supported solid membrane under different experimental conditions. The membrane with the membrane support in the system may be used with different designs for the effective transport of metal ions, i.e. by changing the ratio of the cross-sectional area to the length $(A / l)$ by increasing the membrane length, $l$, while decreasing the cross-sectional area, $A$, of the membrane. Thus, the proposed fiber-supported solid membrane system may be considered as a fiber with a long length and a small cross-sectional area. The separation of rare earth elements was carried out using citric acid as the eluant and a micro-column cation exchange bed [53]. Thus, by maintaining the travel path length and the diameter of the travel band for the separation of rare earth elements, the fiber supported citric acid solid membrane is a useful technique since the ratio of the cross-sectional area, $A$, to the length of the fiber supported membrane, $l$, can be varied as required. Thus, the ratio of the cross-sectional area and the length of membrane is an important aspect to explore for the transport behavior of rare earth elements.

\subsection{Ion exchange of metal ions}

The reactions occurring in the fiber supported solid membrane system are the cation exchange transport of metal ions (M) from the source solution through the membrane ( $\mathrm{R}$ $\mathrm{COOH}$, citric acid bonded to cellulose) to the receiving phase (HL, complexing reagents), given by following equations.

$$
\begin{aligned}
& \mathrm{M}_{\mathrm{s}}^{\mathrm{n}+}+n \mathrm{R}-\mathrm{COOH}_{{ }_{m}} \rightarrow\left(\mathrm{R}-\mathrm{COO}^{-}\right)_{n} \cdot \mathrm{M}^{\mathrm{n}+},_{m}+n \mathrm{H}^{+}, \\
& \left(\mathrm{R}-\mathrm{COO}^{-}\right)_{n} \mathrm{M}^{n+},{ }_{m}+n \mathrm{HL} \rightarrow n \mathrm{R}-\mathrm{COOH}_{{ }_{m}}+\mathrm{ML}_{n}
\end{aligned}
$$

\subsection{Metal ion concentration variation with respect to time}

The interpretation of the obtained data is an important aspect when exploring the transport behavior of metal ions through a fiber supported solid membrane from the source to the receiving phase. With respect to time, the metal ion exchange reaction proceeds via the metal ion with solid membrane in the liquid phase, hence the metal ion concentration in the source phase decreases and that in the receiving phase increases. The metal ion behavior in the membrane cell was studied by estimating the permeability. The permeability coefficient of the metal ion was estimated by the varying metal ion concentration in the source and receiving phases with respect to time. From the slope of the plot of $\log \left(C_{t} / C_{0}\right)$ vs. $t$, the permeability coefficient $(P)$ was determined using the values of $A\left(5.73 \times 10^{-4} \mathrm{~cm}^{2}\right.$, cross-sectional area), $V(15$ $\mathrm{ml}$, volume) and $l(2 \mathrm{~cm}$, length) for different experiments. $\log \left(C_{t} / C_{0}\right)$ with respect to time is given in Figure 3.

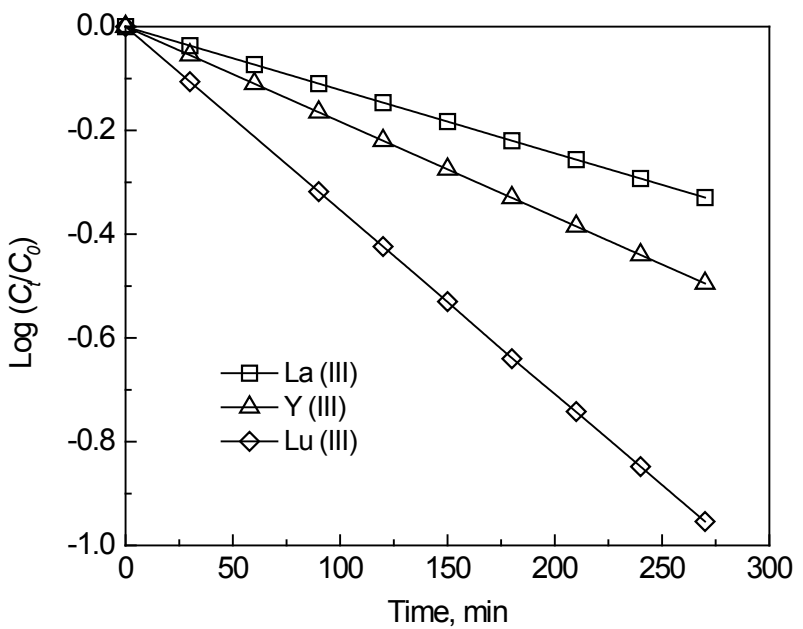

Fig. 3. Plot of $\log \left(C_{t} / C_{0}\right)$ with respect to time 


\subsection{Effect of stirring}

The mechanism of transport of metal ions through the fiber supported solid membrane includes the diffusion of metal ions through the liquid phase and ion exchange of metal ions between the liquid phase and solid membrane cellulose fiber phase. For the transport behavior of metal ions, stirring of the bulk source and receiving phases is essential in order to achieve effective diffusion of chemical species in the bulk solution. Therefore, the source and receiving phases were stirred in the range from 40 to $140 \mathrm{rpm}$. The observed $\log P$ values with respect to stirring speed (rpm) are given in Table 1 . The permeability coefficient $P$ increased with increased stirring speed rpm until $120 \mathrm{rpm}$. After $120 \mathrm{rpm}$, there was no change in the log $P$ value. However, a stirring speed of $125 \mathrm{rpm}$ was used for further experimental studies. The transport behavior of lanthanum, yttrium and lutetium was observed in the transported composition in the order $\mathrm{Lu}>\mathrm{Y}>\mathrm{La}$.

Table 1

Effect of stirring speed on logP values for lanthanum, yttrium and lutetium metal ions, $\mathrm{M}(\mathrm{III})=0.001 \mathrm{M}, \mathrm{HNO}_{3}=1 \mathrm{M}$ and $\mathrm{pH} 5.5$

\begin{tabular}{cccc}
\hline \hline \multirow{3}{*}{$R P M$} & \multicolumn{3}{c}{ Metal ion } \\
\cline { 2 - 4 } & La (III) & Y(III) & Lu (III) \\
\hline 40 & 1.32 & 1.52 & 1.82 \\
60 & 1.51 & 1.73 & 2.01 \\
80 & 1.71 & 1.94 & 2.22 \\
100 & 1.90 & 2.15 & 2.48 \\
110 & 2.10 & 2.30 & 2.56 \\
120 & 2.17 & 2.33 & 2.62 \\
134 & 2.18 & 2.34 & 2.63 \\
140 & 2.17 & 2.33 & 2.62 \\
\hline \hline
\end{tabular}

\subsection{Effect of fiber membrane length}

The transport behavior of rare earth elements depends on the ratio of the cross-sectional area to the length of the fiber supported solid membrane. In order to achieve efficient transport of metal ions, it is necessary to design the membrane cell in different ways. Thus, a new attempt was made to design a membrane cell with the membrane support. The membrane with the membrane support could be designed by changing the ratio of the cross-sectional area to the length $(A / l)$ by increasing the membrane length, $l$, while decreasing the cross-sectional area, $A$, of the membrane. In the present membrane cell, the proposed fiber-supported solid membrane may be considered as a fiber with a long length and a small cross-sectional area. The length of the fiber supported solid membrane determines the time required and the travel path length of rare earth metal ions. Therefore, the length of fiber supported solid membrane was varied in between 1 to $12 \mathrm{~cm}$. The observed $\log P$ values for lanthanum, yttrium and lutetium are given in Table 2. The results show that as the path length of the fiber supported solid membrane increased, the $\log P$ value decreased. For further studies, a path length $2 \mathrm{~cm}$ for the fiber supported solid membrane was used.

Table 2

$$
\begin{aligned}
& \text { Effect of fiber supported solid membrane } \\
& \text { length on logP values for lanthanum, yttrium } \\
& \text { and lutetium metal ions, } \mathrm{M}(\mathrm{III})=0.001 \mathrm{M} \text {, } \\
& \qquad \mathrm{HNO}_{3}=1 \mathrm{M} \text { and } \mathrm{pH} 5.5
\end{aligned}
$$

\begin{tabular}{lccc}
\hline \hline $\begin{array}{l}\text { Fiber supported } \\
\text { membrane length, } \\
\mathrm{cm}\end{array}$ & \multicolumn{3}{c}{ Metal ion } \\
\cline { 2 - 4 } & La (III) & Y (III) & Lu (III) \\
\hline 1 & 2.47 & 2.65 & 2.93 \\
2 & 2.17 & 2.33 & 2.62 \\
3 & 2.10 & 2.25 & 2.53 \\
4 & 2.01 & 2.15 & 2.44 \\
6 & 1.85 & 1.98 & 2.29 \\
8 & 1.69 & 1.81 & 2.14 \\
10 & 1.52 & 1.65 & 1.98 \\
12 & 1.42 & 1.56 & 1.87 \\
\hline \hline
\end{tabular}




\subsection{Effect of the $p H$ of the source phase}

The binding of lanthanum, yttrium and lutetium to the solid membrane depends on the $\mathrm{pH}$ of the source solution, since the dissociation of the metal salt and citric acid in the solid membrane depends on the $\mathrm{pH}$ of the source solution. Therefore, the $\mathrm{pH}$ of the source phase is an effective parameter for the transport behavior of metal ions through a fiber supported solid membrane. In order to avoid the precipitation of lanthanum, yttrium and lutetium metal ions in the alkaline $\mathrm{pH}$ range, the $\mathrm{pH}$ of the source phase, containing the metal ions, was studied from 2 to 6 (Table 3 ). The $\mathrm{pH}$ effect shows that increasing the $\mathrm{pH}$ of the source phase up to 6 caused more exchange of lanthanum, yttrium and lutetium metal ions. Hence, lanthanum, yttrium and lutetium metal ions were effectively transported from the source to the receiving phase. However, a source solution of $\mathrm{pH} 5.5$ was used for further studies.

Table 3

Effect of the pH of the source solution on $\log P$ values for lanthanum, yttrium and lutetium metal ions, $\mathrm{M}(\mathrm{III})=0.001 \mathrm{M}$ and $\mathrm{HNO}_{3}=1 \mathrm{M}$

\begin{tabular}{cccc}
\hline \hline \multirow{2}{*}{$\mathrm{pH}_{\mathrm{s}}$} & \multicolumn{3}{c}{ Metal ion } \\
\cline { 2 - 4 } & $\mathrm{La}(\mathrm{III})$ & $\mathrm{Y}(\mathrm{III})$ & $\mathrm{Lu}(\mathrm{III})$ \\
\hline 2 & 1.31 & 1.43 & 1.69 \\
3 & 1.63 & 1.72 & 2.01 \\
4 & 1.89 & 2.02 & 2.33 \\
5 & 2.18 & 2.34 & 2.63 \\
6 & 2.19 & 2.35 & 2.64 \\
\hline \hline
\end{tabular}

In order to observe the transport behavior of the rare earth metal ions from the source to the receiving solution through the fiber supported solid membrane, it was important to explore additional experimental variables. These experimental variables include the concentration and nature of the stripping agent in the receiving phase. The stripping agent is an essential reagent to enhance the transport of metal ions from the source to the receiving phase. Therefore, different stripping agents were used in the receiving phase.

\subsection{Effect of $\mathrm{HCl}$ and $\mathrm{HNO}_{3}$ concentration}

In order to strip out the metal ions from the fiber supported solid membrane phase, effective strippants are required in the receiving phase. In order to achieve efficient transport of metal ions from the source to the receiving phase through the membrane, different strippants were tested in the receiving phase. $\mathrm{HCl}$ and $\mathrm{HNO}_{3}$ were used in the receiving phase. The transport behavior of the rare earth metal ions lanthanum, yttrium and lutetium were observed, depending on the metal ion complex formation ability or affinity of $\mathrm{HCl}$ or $\mathrm{HNO}_{3}$ for metal ions. In the comparison of $\mathrm{HCl}$ and $\mathrm{HNO}_{3}$ stripping reagents in the receiving phase, $\mathrm{HNO}_{3}$ formed strong complexes has and had greater affinity for rare earth metal ions. The concentrations of $\mathrm{HCl}$ and $\mathrm{HNO}_{3}$ were varied in the receiving phase from 0 to $2.5 \mathrm{M}$. The results show that with an increase in the concentration of $\mathrm{HCl}$ and $\mathrm{HNO}_{3}$ in the range 0 to $2.5 \mathrm{M}$, the permeability coefficients $(P)$ of the rare earth metal ions increased (Figure 4). The transport behavior of lanthanum, yttrium and lutetium was observed in the order $\mathrm{Lu}>\mathrm{Y}>\mathrm{La}$.

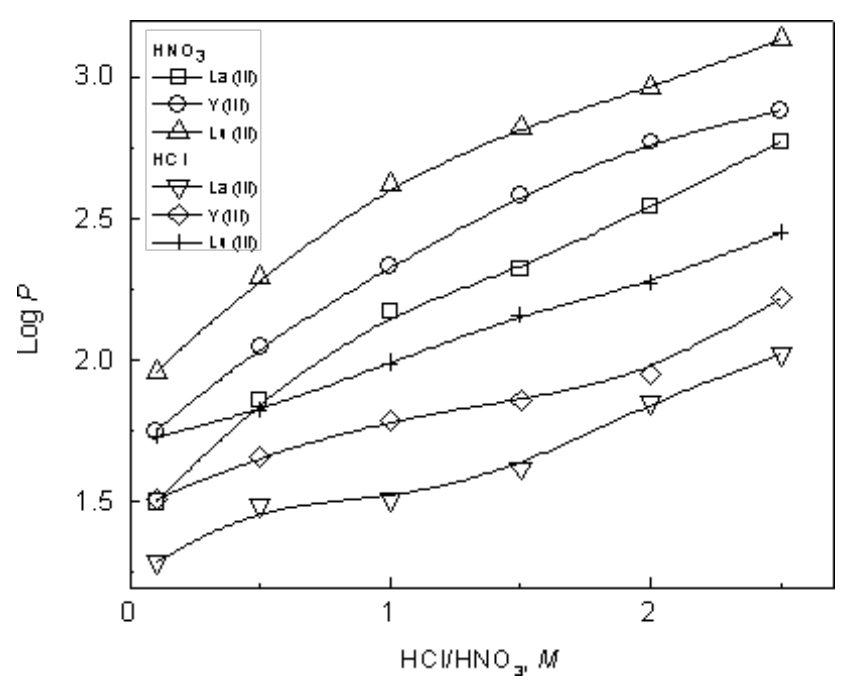

Fig. 4. Effect of nitric and hydrochloric acid on transport of rare earth metal ions,

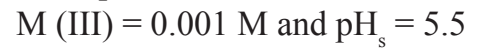




\subsection{Effect of $\mathrm{NaNO}_{3}$ and $\mathrm{NH}_{4} \mathrm{SCN}$ concentration}

Metal ions are extracted by the solid membrane on the source solution side, and these metal ions are stripped out from the solid membrane phase on the receiving phase side. Therefore, it was essential to test the stripping out efficiency of sodium nitrate and ammonium thiocyanate by using them in the receiving phase. For effective transport of rare earth metal ions from the source to the receiving phase through the membrane phase, sodium nitrate and ammonium thiocyanate were tested in the receiving phase. The concentration of sodium nitrate and ammonium thiocyanate in the receiving phase was varied from 0 to $3 \mathrm{M}$. The permeability coefficient $(P)$ increased with an increased concentration from 0 to $3 \mathrm{M}$ (Figure 5).

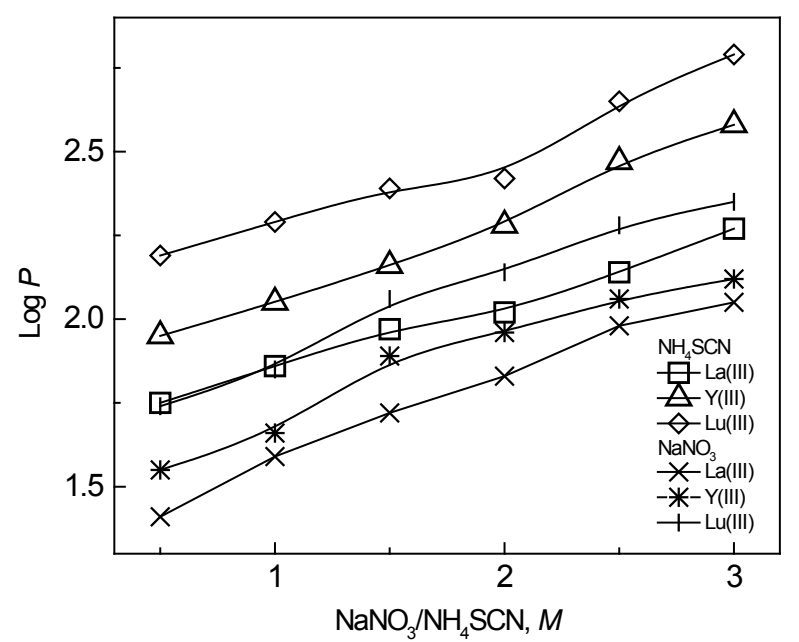

Fig. 5. Effect of sodium nitrate and ammonium thiocyanate on the transport of rare earth metal ions,

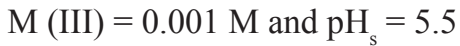

\subsection{Effect of beta-diketone and $D_{2}$ EHPA concentration}

Mineral acids, water soluble complexing agents, alkali metals and ammonium salts have been used as strippants in the receiving phase. Here, new attempts were made to use these extractants as stripping reagents. Beta-diketone and $\mathrm{D}_{2} \mathrm{EHPA}$ as extractants in toluene were used in the receiving phase.
The purpose behind the use of beta-diketone and $\mathrm{D}_{2}$ EHPA was to enhance the transport of metal ions from the source phase where both extractants form strong metal complexes with rare earth metal ions. The concentration of beta-diketone and $\mathrm{D}_{2}$ EHPA was varied from 0.001 to $0.01 \mathrm{M}$. The results showed increased permeability coefficients $(P)$ of the rare earth metal ions (Figure 6) with increasing beta-diketone and $\mathrm{D}_{2}$ EHPA concentration.

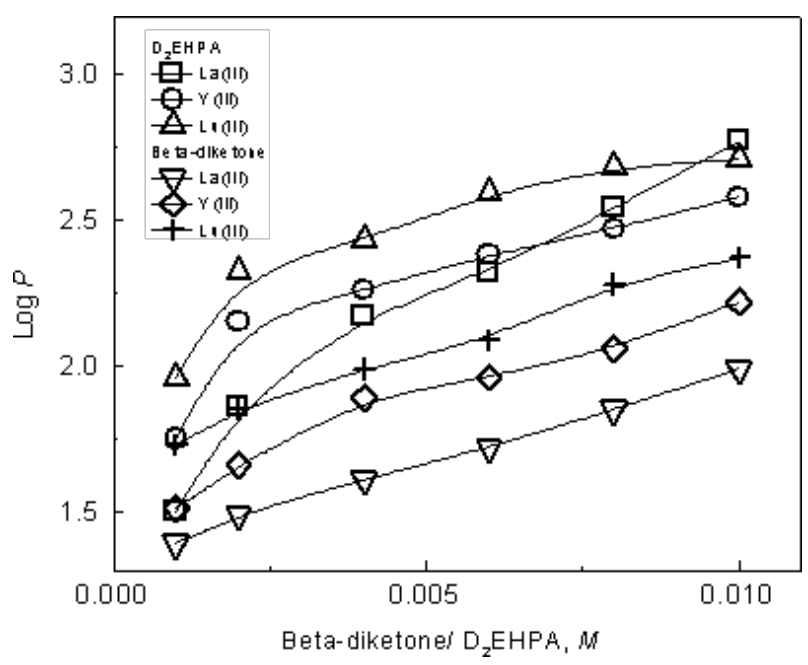

Fig. 6. Effect of beta-diketone and $\mathrm{D}_{2} \mathrm{EHPA}$ on the transport of rare earth metal ions,

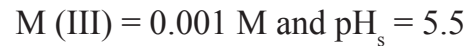

\subsection{Effect of Versatic 10 and naphthenic acid concentration}

Bulky and long chain organic carboxylic acids such as Versatic 10 and naphthenic acid can be used as extractants for rare earth metal ions from the aqueous phase. Here, attempts were to use these extractants as the stripping reagent. Versatic 10 and naphthenic acids were used in toluene in the receiving phase in order to check the effective transport of rare earth metal ions through the fiber supported solid membrane. The concentration of Versatic 10 and naphthenic acids in toluene was varied in the receiving phase from 0.001 to $0.01 \mathrm{M}$. The observed permeability coefficient $(P)$ increased with an increased concentration of these acids (Figure 7). 


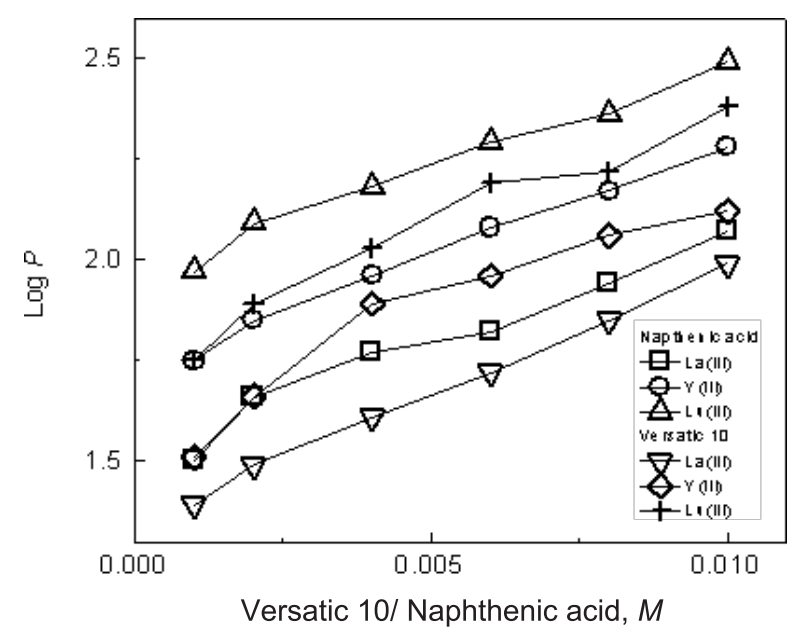

Fig. 7. Effect of Versatic 10 and naphthenic acid on the transport of rare earth metal ions,

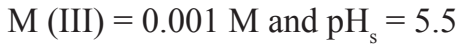

\subsection{Effect of EDTA and tartaric acid concentration}

EDTA and tartaric acid form strong complexes with rare earth metal ions. EDTA and tartaric acid can be used as strippants for rare earth metal ions. EDTA and tartaric acid were tested in the receiving phase for the transport of rare earth metal ions from the source to the receiving phase through the fiber supported solid membrane. The concentration of EDTA and tartaric acid in the receiving phase was varied from 0.001 to $0.02 \mathrm{M}$. The results show that the permeability coefficient $(P)$ increased with an increased concentration of EDTA and tartaric acid from 0.001 to $0.02 \mathrm{M}$ (Figure 8 ).

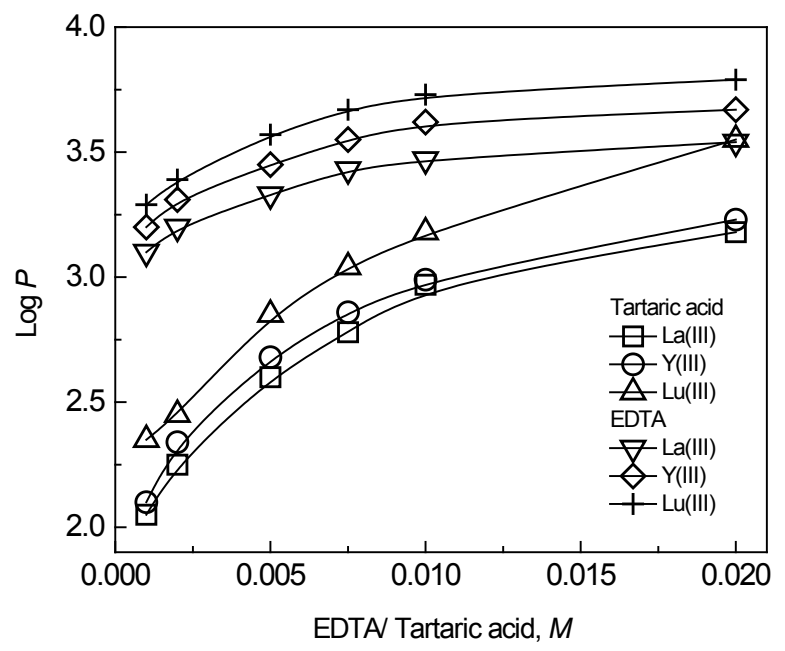

Fig. 8. Effect of EDTA and tartaric acid on the transport

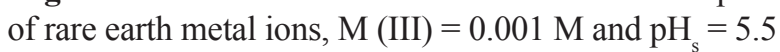

\subsection{Effect of mixed solvents}

In order to explore the effect of organic solvents, since, the organic solvent has low dielectric constant and favors the ion pair formation, nitrate and thiocyanate anions were tested in a mixed solvent in the receiving phase for the transport of rare earth metal ions. Controlled proportions of nitric acid and ammonium thiocyanate, $\mathrm{H}_{2} \mathrm{O}$, TBP, Aliquat-336 and the organic solvents methanol, ethanol, 2-propanol, acetone, 1,4-dioxane and tetrahydrofuran were used.

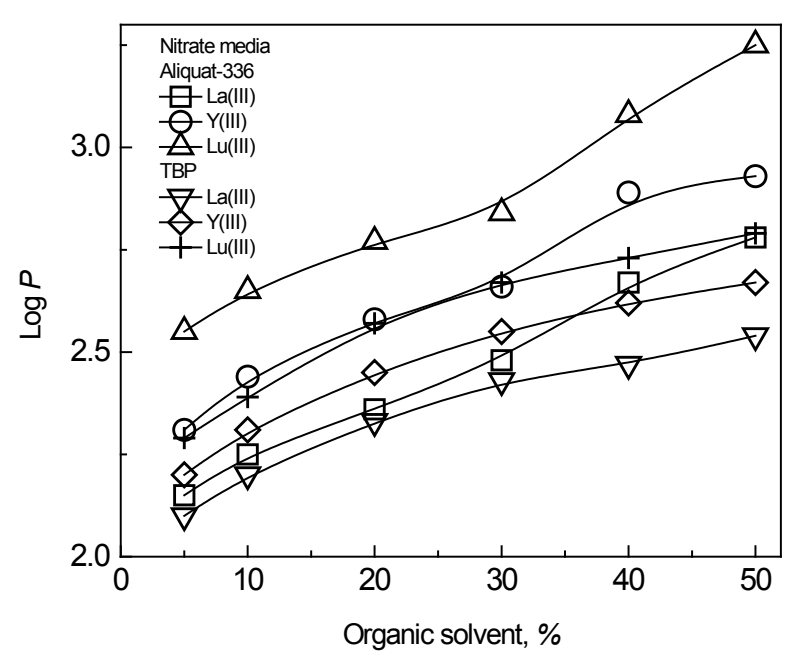

Fig. 9. Effect of an organic solvent on the transport of rare earth metal ions in nitrate media,

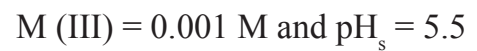

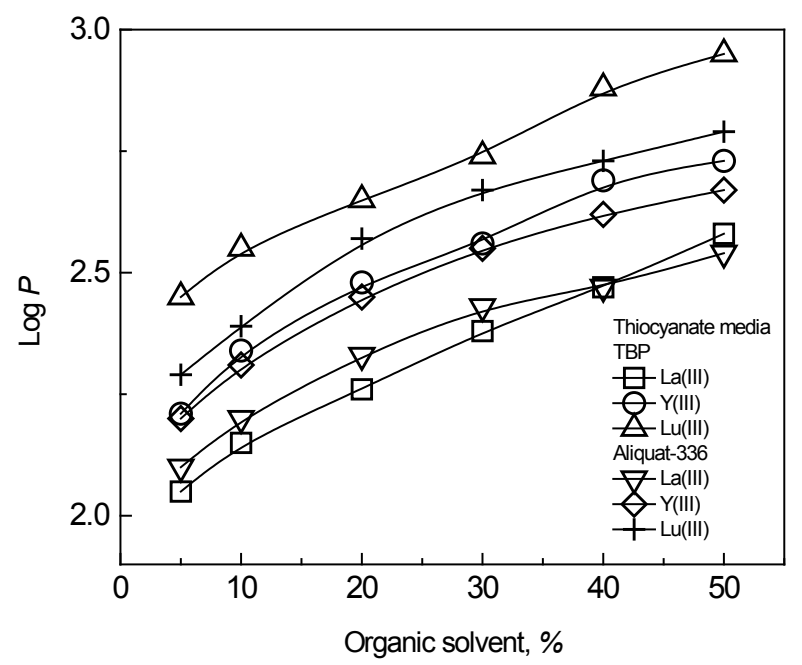

Fig. 10. Effect of an organic solvent on the transport of rare earth metal ions in thiocyanate media,

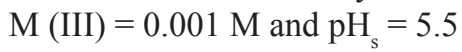


A mixture of $\mathrm{HNO}_{3}$ or ammonium thiocyanate, organic solvent such as methanol, ethanol, 2-propanol, acetone, 1,4-dioxane, tetrahydrofuran and TBP (tributyl phosphate) or Aliquat-336 favors the ion pair formation and hence enhances the metal ion transport to the receiving phase. In Figures 9 and 10, $\log P$ vs. the percentage of the organic solvent acetone in conjunction with nitric acid or ammonium thiocyanate in TBP or Aliquat 336 is shown. The increased percentage of the organic solvent in conjunction with salt increased the $\log P$ of the metal ions.

\subsection{Variation in $\log P$ with different mixed solvents}

For the aspects of metal ion transport, the role of organic solvents such as acetone and trioctyl phosphine oxide (TOPO) in the receiving phase was explored. $\log P$ values were determined for the different compositions of nitric acid and an organic solvent, such as acetone, and $0.01 \mathrm{M}$ trioctyl phosphine oxide (TOPO). The metal ion transport of lanthanum, yttrium, and lutetium were studied using nitric acid and organic solvents in mixed systems including TOPO. The chemical properties of the metal ions, such as nitro complex formation, solvation and ion exchange, are important factors involved in the transport of lanthanum, yttrium and lutetium metal ions. $\log P$ values were determined for the different combinations of nitric acid and organic solvents at $0.01 \mathrm{M}$ TOPO. The combinations of nitric acid and the organic solvent were useful for the selective transport of metal ions from the source to the receiving phase (Table 4).

The transport of lanthanum, yttrium and lutetium metal ions through the fiber supported solid membrane was observed in the sequence of decreasing efficiency: chemically modified fiber (mixed solvents $\mathrm{HNO}_{3}+$ organic solvent + TOPO as the stripping agent in the receiving phase) $>$ chemically modified fiber (mixed solvents $\mathrm{HNO}_{3}+$ organic solvent as the strip- ping agent in the receiving phase) $>$ chemically modified fiber (mineral acids as the stripping agent in the receiving phase). The efficiency of the organic solvents in the mixed solvents can be arranged in decreasing order: TOPO + tetrahydrofuran $>\mathrm{TOPO}+1,4$ dioxane $>\mathrm{TOPO}+$ acetone $>\mathrm{TOPO}+2$-propanol $>\mathrm{TOPO}+$ ethanol $>$ TOPO + methanol $>$ TOPO .

Table 4

LogP values for some rare earth metal ions in the mixed solvents of $1 \mathrm{M} \mathrm{HNO}_{3}$ and

0.01M TOPO containing organic solvent, $M(I I I)=0.001 \mathrm{M}$ and $\mathrm{H}_{\mathrm{s}} 5.5$

\begin{tabular}{|c|c|c|c|c|}
\hline \multirow{2}{*}{ Metal ion } & \multicolumn{4}{|c|}{ Organic solvent } \\
\hline & $20 \%$ & $40 \%$ & $60 \%$ & $80 \%$ \\
\hline \multicolumn{5}{|c|}{ Methanol } \\
\hline La (III) & 1.52 & 1.63 & 1.72 & 1.84 \\
\hline Y(III) & 1.69 & 1.79 & 1.90 & 1.99 \\
\hline $\mathrm{Lu}(\mathrm{III})$ & 1.80 & 1.89 & 1.98 & 2.09 \\
\hline \multicolumn{5}{|c|}{ Ethanol } \\
\hline $\mathrm{La}$ (III) & 1.55 & 1.66 & 1.74 & 1.90 \\
\hline $\mathrm{Y}(\mathrm{III})$ & 1.65 & 1.82 & 1.93 & 2.03 \\
\hline $\mathrm{Lu}$ (III) & 1.84 & 1.93 & 2.04 & 2.19 \\
\hline \multicolumn{5}{|c|}{ 2-Propanol } \\
\hline $\mathrm{La}$ (III) & 1.58 & 1.69 & 1.82 & 1.92 \\
\hline $\mathrm{Y}(\mathrm{III})$ & 1.72 & 1.85 & 1.95 & 2.14 \\
\hline $\mathrm{Lu}$ (III) & 1.84 & 1.97 & 2.17 & 2.29 \\
\hline \multicolumn{5}{|c|}{ Acetone } \\
\hline $\mathrm{La}$ (III) & 1.63 & 1.74 & 1.87 & 1.95 \\
\hline Y (III) & 1.79 & 1.89 & 2.02 & 2.13 \\
\hline $\mathrm{Lu}$ (III) & 1.89 & 1.98 & 2.11 & 2.27 \\
\hline \multicolumn{5}{|c|}{ 1,4-Dioxane } \\
\hline $\mathrm{La}$ (III) & 1.65 & 1.77 & 1.89 & 1.99 \\
\hline Y (III) & 1.82 & 1.91 & 2.02 & 2.12 \\
\hline $\mathrm{Lu}$ (III) & 1.87 & 1.99 & 2.12 & 2.21 \\
\hline \multicolumn{5}{|c|}{ Tetrahydrofuran } \\
\hline $\mathrm{La}$ (III) & 1.67 & 1.79 & 1.92 & 2.05 \\
\hline Y (III) & 1.83 & 1.97 & 2.05 & 2.15 \\
\hline Lu (III) & 1.95 & 2.05 & 2.15 & 2.29 \\
\hline
\end{tabular}




\subsection{Separation of lanthanum from binary mixtures}

The separation factor [54-55] $\alpha, \alpha=P_{1} /$ $P_{2}$, for two metal ions can be used for selective transport of metal ions from the source phase through the fiber supported solid membrane. $P_{1}$ is the permeability coefficient of a metal ion which is weakly bound and selectively favorable to nitrate/chloride ion complex formation. $P_{2}$ is the permeability coefficient of a strongly bound metal ion that is less selectively favorable to nitrate/chloride ion complex formation. For example, La is relatively strongly bound; however, other foreign ions are weakly bound in comparison with lanthanum. Therefore, La moves slowly.

Metal ion transport was studied in binary mixtures using hydrochloric/nitric acid and organic solvents. The amount of metal ions in the source solution is given in the Table 5. The separation of $\mathrm{La}$ (III) metal ions from zinc, copper, iron, cobalt, manganese, nickel, beryllium, titanium, aluminum, calcium, magnesium, potassium, bismuth, cadmium, lead, indium, gallium, thallium, gold, palladium and platinum metal ions was carried out from the source phase through the fiber supported solid membrane. $0.5 \mathrm{M} \mathrm{HCl}$ in the receiving phase was used for lithium and sodium. However, 0.5 M $\mathrm{HCl}$ in $20 \%$ TBP and $60 \%$ tetrahydrofuran in the receiving phase was used for $\mathrm{As}, \mathrm{Sb}, \mathrm{Cd}$, $\mathrm{Pb}$ and $\mathrm{Bi}$. $0.5 \mathrm{M} \mathrm{HCl}$ in $80 \%$ acetone in the receiving phase was used for zinc, copper, iron, cobalt, manganese, nickel, indium, gallium and thallium. Moreover, $0.25 \mathrm{M} \mathrm{HCl}$ in $80 \%$ tetrahydrofuran in the receiving phase was used for gold, palladium and platinum metal ions. Lanthanum metal ions remained in the source solution and membrane phase.

Table 5

The transport of La(III) $=0.15 \mathrm{mmol}$ from binary mixtures in mixed solvent systems

\begin{tabular}{|c|c|c|c|c|}
\hline Foreign ions & $\begin{array}{l}\text { Foreign ions } \\
\text { amount added mmol }\end{array}$ & $\begin{array}{l}\text { La (III) found, } \\
\text { mmol }\end{array}$ & Recovery (\%) & $\begin{array}{l}\text { Mixed solvents } \\
\text { for other metal ions }\end{array}$ \\
\hline $\operatorname{Li}(\mathrm{I})$ & 0.20 & 0.15 & 100 & $0.5 \mathrm{M} \mathrm{HCl}$ \\
\hline $\mathrm{Na}(\mathrm{I})$ & 0.15 & 0.149 & 99.3 & \\
\hline As(III) & 0.15 & 0.15 & 100 & $0.25 \mathrm{M} \mathrm{HCl}$ in $20 \% \mathrm{TBP}$ \\
\hline $\mathrm{Sb}(\mathrm{III})$ & 0.15 & 0.15 & 100 & in $60 \%$ tetrahydrofuran \\
\hline $\operatorname{Sn}(\mathrm{III})$ & 0.15 & 0.15 & 100 & \\
\hline $\mathrm{Cd}(\mathrm{II})$ & 0.20 & 0.20 & 100 & \\
\hline $\mathrm{Pb}(\mathrm{II})$ & 0.20 & 0.20 & 100 & \\
\hline Bi(III) & 0.20 & 0.20 & 100 & \\
\hline In(III) & 0.15 & 0.15 & 100 & $0.5 \mathrm{M} \mathrm{HCl}$ in $80 \%$ acetone \\
\hline $\mathrm{Ga}(\mathrm{III})$ & 0.15 & 0.15 & 100 & \\
\hline $\mathrm{Tl}(\mathrm{III})$ & 0.15 & 0.15 & 100 & \\
\hline $\mathrm{Zn}(\mathrm{II})$ & 0.20 & 0.15 & 100 & \\
\hline $\mathrm{Cu}(\mathrm{II})$ & 0.20 & 0.20 & 100 & \\
\hline $\mathrm{Fe}(\mathrm{III})$ & 0.20 & 0.20 & 100 & \\
\hline $\mathrm{Mn}(\mathrm{II})$ & 0.20 & 0.20 & 100 & \\
\hline $\mathrm{Co}(\mathrm{II})$ & 0.20 & 0.20 & 100 & \\
\hline $\mathrm{Ni}(\mathrm{II})$ & 0.20 & 0.20 & 100 & \\
\hline $\operatorname{Pd}(\mathrm{II})$ & 0.15 & 0.15 & 100 & $0.25 \mathrm{M} \mathrm{HCl}$ in $80 \%$ tetrahydrofuran \\
\hline $\operatorname{Pt}(\mathrm{IV})$ & 0.15 & 0.15 & 100 & \\
\hline $\mathrm{Au}(\mathrm{III})$ & 0.15 & 0.15 & 100 & \\
\hline
\end{tabular}




\subsection{Pre-concentration of rare earth metal ions}

The pre-concentration of lanthanum, yttrium and lutetium metal ions was carried out from dilute solutions in the concentration range of $10^{-3}$ to $10^{-6} \mathrm{M}$. In Table 6 , the pre-concentration of lanthanum, yttrium and lutetium metal ions is illustrated. It was observed that the preconcentration of lanthanum, yttrium and lutetium metal ions from dilute solutions was quite effective.

T a b 1 e 6

\section{EF values for lanthanum, yttrium and} lutetium metal ions in mixed solvents with variable metal ion concentrations

\begin{tabular}{cccc}
\hline \hline \multirow{2}{*}{$\begin{array}{c}\text { Metal ion, } \\
\log [\mathrm{M}]\end{array}$} & \multicolumn{3}{c}{ Metal ion } \\
\cline { 2 - 4 } & $\mathrm{La}(\mathrm{III})$ & $\mathrm{Y}(\mathrm{III})$ & $\mathrm{Lu}(\mathrm{III})$ \\
\hline-3 & 2.56 & 2.79 & 2.99 \\
-4 & 2.73 & 3.12 & 3.28 \\
-5 & 3.53 & 3.78 & 3.99 \\
-6 & 4.36 & 4.64 & 4.89 \\
\hline \hline
\end{tabular}

\section{CONCLUSION}

Cellulose fiber modified with citric acid was used for the transport of metal ions. The effect of time, stirring of the bulk phases, fiber membrane length, the $\mathrm{pH}$ of the source phase and different complexing agents in the receiving phase was explored in the transport and separation of metal ions through the fiber supported solid membrane. Foreign metal ions were removed from lanthanum in a mixed solvent system. The proposed novel cellulose fiber supported solid membrane is useful for the transport of rare earth metal ions from the source to the receiving phase.

\section{REFERENCES}

[1] K. Bril, S. Bril, P. Krumholz, Separation of metal ions by means of ion-exchange membranes. I. Separation of rare earth mixtures, and of thorium-rare earth mixture using ethylene diamine tetraacetic acid, Phys. Chem., 63 (2), 256-259 (1959).

[2] S. Umetani, S. Tsurubou, T. Sasaki, Y. Komatsu, Macrocyclic ligand as ion size selective masking reagent in metal ion separation, Riken Rev., 35, 110-114 (2001)

[3] M. R. Yaftian, M. Burgard, C. B. Dieleman, D. Matt, Rare-earth metal-ion separation using a supported liquid membrane mediated by a narrow rim phosphorylated calix[4]arene, J. Membr. Sci., 144 (1-2), 57-64 (1998).

[4] T. Uda, K.T. Jacob, M. Hirasawa, Technique for enhanced rare earth separation, Science, 289, 2326-2329 (2000).

[5] S. Zhiquan, Z. Fuyao, Z. Yifeng, Pervaporation separation of water-acetic acid mixtures through an co-AA membrane treated with rare earth metal ions, Chin. J. Poly. Sci., 13(2), 185-188 (1995).

[6] D. Ishii, A. Hirose, Y. Iwasaki, Cation exchange separation of 16 rare earth metals by microscale high-performance liquid chromatography, $J$. Radioanalyt. Chem., 48, 41-49 (1978).

[7] S. Nishihama, T. Hirai, I. Komasawa, Advanced liquid-liquid extraction systems for the separation of rare earth ions by combination of conversion of the metal species with chemical reaction, J. Solid State Chem., 171, 101-108 (2003).

[8] S. Nishihama, N. Sakaguchi, T. Hirai, I. Komasawa, Extraction and separation of rare earth metals using microcapsules containing bis(2-ethylhexyl) phosphinic acid, Hydrometallurgy, 64(1), 35-42 (2002).

[9] T. Araki, T. Okazawa, Y. Kubo, H. Ando, H. Asai, Separation of lighter rare earth metal ions by centrifugal countercurrent type chromatography with di-(2-ethylhexyl)phosphoric acid J. Liq. Chromatogr., 11(1), 267-281 (1988).

[10] D. O. Campbell, Rapid rare earth separation by pressurized ion exchange chromatography, J. Inorg. Nuc. Chem., 35(11), 3911-3919 (1973).

[11] R. G. Fernandez, J. L. G. Alonso, Separation of rare earth elements by anion-exchange chromatography using ethylene diamine tetraacetic acid as mobile phase, J. Chromatogr. A, 1180 (1-2), 59-60 (2008). 
[12] P. Liang, W. Liming, G. Wei, Separation of trivalent samarium through facilitated stripping dispersion hollow fiber liquid membrane using ( $\mathrm{D}_{2}$ EHPA) as mobile carrier, Chin. J. Chem., 29, 1233-1238 (2011).

[13] S. A. Abo Farha, N. A. Badawy, A. A. El-Bayaa, S. E. Garamon, The effect of chelating agent on the separation of some metal ions from binary mixture solution by cation-exchange resin, Nature and Science, 8(10), 16-25 (2010).

[14] P. G. Manning, Tartrate complexes of the rare-earth elements I, d-, di-, and meso tartrate complexes of $\mathrm{Tb}$ and Eu, Cana. J. Chem., 41, 2557-2565 (1963).

[15] C. Pin, S. Joannon, Combined cation-exchange and extraction chromatography for the concomitant separation of $\mathrm{Zr}$, Hf, Th, and the lanthanides from geological materials, Talanta, 57, 393-403 (2002).

[16] C. A. Morias, V. S. T. Ciminelli, Process development for the recovery of high-grade lanthanum by solvent extraction, Hydrometallurgy, 73, 237-244 (2004).

[17] L. Hernández, A. M. Bolarín, F. Sánchez, F. Patiño, I. Rivera, E. Salinas, Studies on ion transport of $\mathrm{Eu}(\mathrm{III})$ and $\mathrm{Gd}(\mathrm{III})$ through supported liquid membranes containing di-(2-ethylhexyl) phosphate, as a carrier, J. Mex. Chem. Soc., 51(2), 113116 (2007).

[18] D. S. Flett, Solvent extraction in hydrometallurgy: the role of organophosphorus extractants, $J$. Organomett. Chem., 690 (10), 2426-2438 (2004).

[19] D. Zheng, N. B. Gray, G. W. Stevens, Comparison of naphthenic acid, versatic acid and $\mathrm{D}_{2}$ EHPA for the separation of rare earths, Solv. Extr. Ion Exch., 9 (1), 85-102 (1991).

[20] J. S. Preston, Solvent extraction of metals by carboxylic acids, Hydrometallurgy, 14(2), 171-188 (1985).

[21] A. C. du Preez, J. S. Preston, The solvent extraction of rare-earths metals by carboxylic acids, Solv. Extr. Ion Exch., 10 (2), 207-230 (1992).

[22] F. Miller, Carboxylic acids as metal extractants, Talanta, 21(7), 685-801 (1974).

[23] L.D. Nghiem, P. Mornane, I. D. Potter, J. M. Perera, R. W. Cattrall, S. D. Kolev, Extraction and transport of metal ions and small organic compounds using polymer inclusion membranes (PIMs), $J$. Membr. Sci., 281(1-2), 7-41 (2006).

[24] M. R. Yaftian, M Burgard, C. B. Dieleman, D. Matt, Rare-earth metal-ion separation using a sup- ported liquid membrane mediated by a narrow rim phosphorylated calix[4]arene, J. Membr. Sci., 144(1-2), 57-64 (1998).

[25] M. Goto, T. Kakoi, N. Yoshii, K. Kondo, F. Nakashio, Effect of synthesized surfactants in the separation of rare earth metals by liquid surfactant membranes, Ind. Eng. Chem. Res., 32 (8), 16811685 (1993).

[26] F. Kubota, Y. Shimobori, Y. Koyanagi, K. Shimojo, N. Kamiya, M. Goto, Uphill transport of rareearth metals through a highly stable supported liquid membrane based on an ionic liquid, Anal. Sci., 26(3), 289-290 (2010).

[27] N. M. Kocherginsky, Q. Yang, L. Seelam, Recent advances in supported liquid membrane technology, Sepn. Purifi. Technol., 53, 171-177 (2007).

[28] P. Liang, W. Liming, Y. Guoqiang, Separation of $\mathrm{Eu}(\mathrm{III})$ with supported dispersion liquid membrane system containing $\mathrm{D}_{2}$ EHPA as carrier and $\mathrm{HNO}_{3}$ solution as stripping solution, J. Rare Earths., 29 (1), 7-14 (2011).

[29] R. Bautista, Advances in rare earths separation and purification, Miner. Process. Extract. Metallur. Rev., 8 (1-4), 175-182 (1992).

[30] A. A. Kopyrin, A. A. Fomichev, M. A. Afonin, T. Todd, New methodological approach to investigation of kinetics of rare earth elements (REE) extraction in nonstationary conditions, $J$. Rare Earths., 25 (4), 385-391 (2007).

[31] M. Matsumoto, Ionic liquid-based supported liquid membranes, Membrane technologies and applications, edited by M. K. Purkait, CRC Press, pp. 305-316, 2011.

[32] P. Liang, W. Liming, Y. Guoqiang, Study on a novel flat renewal supported liquid membrane with $\mathrm{D}_{2}$ EHPA and hydrogen nitrate for neodymium extraction, J. Rare. Earths, 30(1), 63-68 (2012).

[33] Y. Xianwang, L. Lanming, G. Banghui, Rare earth recovery by supported liquid membrane, Transactions Nfsoc., 4(1), 54-58 (1994).

[34] D. de Agreda, I. G. Diaz, F. A. López, F. J. Alguacil, Supported liquid membranes technologies in metals removal from liquid effluents, Revista Metalurgia, 47 (2), 146-168 (2011).

[35] L. D. Nghiema, P. Mornanea, I. D. Potter, J. M. Perera, R. W. Cattrall, S. D. Kolev, Extraction and transport of metal ions and small organic compounds using polymer inclusion membranes (PIMs), J. Membr. Sci., 281, 7-41 (2006).

[36] B. Wen, X. Shan, S. Xu, Pre-concentration of ul- 
tra-trace rare earth elements in seawater with 8-hydroxyquinoline immobilized poly-acrylonitrile hollow fiber membrane for determination by inductively coupled plasma mass spectrometry, $\mathrm{An}$ alyst, 124, 621-626 (1999).

[37] B. Y. Spivakov, V. M. Shkinev, K. E. Geckeler, Separation and pre-concentration of trace elements and their physico- in chemical forms in aqueous media using inert solid membranes, Pure. Appl. Chem., 66 (3), 631-640 (1994).

[38] R. D. Ambashta, M.E.T. Sillanpää, Membrane purification in radioactive waste management: A short review, J. Environ. Radioacti., 105, 76-84 (2012).

[39] V. Camel, Solid phase extraction of trace elements, Spectrochimica Acta. B., 58, 1177-1233 (2003).

[40] R. D. Noble, C. A. Koval, J. J. Pellegrino, Facilitated transport membrane systems, Chem. Ena. Progr., 58-70 (1989).

[41] J. Korkisch, Combined ion exchange-solvent extraction: A new dimension in inorganic separation chemistry, Nature, 210, 626-627 (1966).

[42] L. R. Snyder, J. W. Dolan, High-performance gradient elution: The practical application of the linearsolvent-strength model, Wiley Interscience, 2006.

[43] A. de Lucas, J. L. Valverde, M. C. Romero, J. Gómez, J. F. Rodríguez, Ion Exhange equilibria in nonaqueous and mixed solvents on the cationic exchanger Amberlite IR-120, J. Chem. Eng. Data, 46, 73-78 (2001).

[44] O. D. Bonner, Use of ion exchange resins with nonaqueous and mixed solvents, J. Chem. Educ., 34 (4), 174-177 (1957).

[45] O. D. Bonner, J. C. Moorefield, Ion exchange in mixed solvents, J. Phys. Chem., 58 (7), 555-557 (1954).

[46] H. E. van Wart, G. E. Janauer, Cation exchange in mixed solvent media. I. Equilibrium swelling of polystyrenesulfonate resins in dimethyl sulfoxide-water media, J. Phys. Chem., 78 (4), 411-417 (1974).
[47] G. Remin, R. Hu, Y. C. Jian, C. Fayang, L. Zhili, A cellulose-based carboxyl cotton chelator having citric acid as an anchored ligand: preparation and application as solid phase extractant for copper determination by flame atomic absorption spectrometry, Microchimica Acta, 158, 315-320 (2007).

[48] M. Yu, D. Sun, W. Tian, W. Shena, H. Zhanga, N. Xua, Systematic studies on adsorption of trace elements Pt, Pd, Au, Se, Te, As, Hg, Sb on thiol cotton fiber, Anal. Chim. Acta, 456, 147-155 (2002).

[49] G. Renmin, K. Zhong, Y. Hu, J. Chen, G. Zhu, Thermochemical esterifying citric acid onto lignocellulose for enhancing methylene blue sorption capacity of rice straw, J. Environ. Managem., 88, 875-880 (2008).

[50] S. Sungur, S. Babglu, Synthesis of a new cellulose ion exchanger and use for the separation of heavy metals in aqueous solutions, Sepn. Sci. Technol., 40 (10), 2067-2078 (2005).

[51] R. E. Wing, Cellulosic citrates: preparation and ion exchange properties, J. Poly. Mater., 14, 303-309 (1997).

[52] T. Vaughan, C. W. Seo, W. E. Marshall, Removal of selected metal ions from aqueous solution using modified corncobs, Bioresour. Technol., 78(2), 133-139 (2001).

[53] P. Alimarin, V. Y. Jakovlev, A. Z. Miklishansky, N. N. Dogadkin, O. V. Stepanets, Determination of dysprosium, europium, samarium and gadolinium in yttrium oxide of high purity by means of neutron activation analysis, J. Radioanalyt. Chem., 1(2), 139-145 (1968).

[54] P. R. Danesi, Separation of metal species by supported liquid membranes, Sepn. Sci. Technol., 19, 857-894 (1984-1985).

[55] A. N. Turanov, V. K. Karandashev, V. E. Baulin, Extraction of rare-earth elements and americium from nitric acid solutions with polyphosphine oxides, Radiochem., 44(1), 26-34 (2002). 
